\title{
IMAGEM E EPIFANIA NOS POEMAS EM PROSA DE CRUZ E SOUSA ${ }^{1}$
}

\section{IMAGE AND EPIPHANY IN CRUZ E SOUSA'S PROSE POETRY}

Antônio Donizeti PIRES²

RESUMO: Partindo da conceituação de termos caros à teoria e à crítica da poesia lírica, perfaço um breve estudo da poesia em prosa do simbolista brasileiro Cruz e Sousa (1861-1898), consubstanciada nos livros Missal (1893) e Evocações (1898). Procurei evidenciar o processo de composição das duas obras e as diferenças entre ambas, frisando inclusive o modo pelo qual o poeta configura suas imagens poéticas. Assim, articulando os conceitos de Imagem e Epifania - utilizados pelo poeta de maneira moderna e original -, busquei ressaltar sua importância no processo construtivo de Cruz e Sousa, salientando, por fim, o lugar de destaque que o poeta ocupa nos quadros da poesia brasileira.

PALAVRAS-CHAVE: Poesia brasileira; Simbolismo; poema em prosa; imagem; epifania.

ABSTRACT: Starting from the conceptualization of some important terms to the theory and to the critic of lyric poetry, we conducted a brief study of the Brazilian symbolist Cruz e Sousa's (1861-1898)

\footnotetext{
${ }^{1}$ Trabalho inédito, apresentado em comunicação no "Simpósio Nacional Trans-posições e Trans-formações. 0 texto da imagem e a imagem no texto" (UNICAMP, novembro de 2005). Trata-se de resumo da tese de doutoramento que defendi em 2002, junto ao PPG em Estudos Literários da UNESP/Araraquara, intitulada Pela volúpia do Vago: o Simbolismo. 0 poema em prosa nas literaturas portuguesa e brasileira.

${ }^{2}$ Docente da Universidade Estadual Paulista Júlio de Mesquita Filho/ UNESP, câmpus de Araraquara.adpires@fclar.unesp.br.
} 
prose poetry, consubstantiated in the works Missal (1893) and Evocações (1898). We tried to evidence the composition process of both books as well as the differences between them, stressing the way the poet configures his poetic images. Thus, articulating the concepts of Image and Epiphany - used by the poet in a modern and original way -, we aimed to emphasize their importance in Cruz e Sousa constructive process and the importance of the poet in the Brazilian poetry.

KEYWORDS: Brazilian Poetry; Symbolism; Prose Poetry; Image; Epiphany.

\section{Poesia lírica, poema em prosa, ritmo, imagem, epifania}

Maurice-Jean Lefebve, em Estrutura do discurso da poesia e da narrativa(1980), argumenta que a linguagem da poesia lírica é carregada de intencionalidade, e que esta se concretiza na materialidade e na figuralidade. A primeira é concebida como a "consistência que ganha a linguagem no discurso literário" (LEFEBVE, 1980, p. 87), enquanto a figuralidade é condição estruturante deste, uma vez que todos os componentes de um poema, desde as clássicas figuras de retórica até a rima, a versificação ou as imagens, são figuras deliberadamente escolhidas pelo poeta. A materialidade, fechada num todo coeso, orgânico e autônomo, se presentifica, se abre e se atualiza sempre que o leitor a inquire e a perquire.

Jean Cohen, em Estrutura da linguagem poética(1978), destaca o fato de a "poetização abrange[r] os dois níveis da linguagem, o fônico e o semântico" (COHEN, 1978, p. 46). A partir deste duplo aspecto, Cohen analisa a estrutura da linguagem poética ligando a versificação(os elementos formais, significantes, do poema) ao nível fônico, enquanto a predicação(os conteúdos, os significados presentes no poema) ligase ao nível semântico. A exemplo de Lefebve, Cohen considera como figuras os vários elementos fundamentais do texto poético, pois todas 
as figuras por este apresentadas têm por efeito "provocar o processo metafórico. A estratégia poética tem por único objetivo a mudança de sentido" (COHEN, 1978, p. 95). Na perspectiva do crítico, a metáfora não é apenas uma figura de embelezamento ou obscurecimento do discurso, mas a soma geral de todas as outras figuras, em nível fônico e semântico: estas, coroadas pela metáfora, são responsáveis pela consolidação do discurso único da poesia.

Os dois críticos tratam da poesia versificada, mas suas considerações se aplicam claramente ao poema em prosa, conquanto Cohen o considere mais vincado pela predicação (nível semântico, dos significados em várias camadas) e menos pelo nível fônico/sonoro/musical (com o que, evidentemente, não se pode concordar, uma vez que o poema em prosa de Cruz e Sousa - e de vários outros autores românticos, simbolistas ou vanguardistas - é profusa e profundamente calcado na melopeia, que se conjuga, estruturalmente, à fanopeia e à logopeia, conforme se verá adiante. De todo modo, é assente que o poema em prosa é um subgênero lírico advindo do Romantismo, e que pode ser tido, por seu caráter subversivo e transgressor, como um modo privilegiado de se fazer e de se pensar a poesia na modernidade. Com efeito, vê-se que das figuras fundamentais do discurso poético tradicional (o verso, o metro, a estrofe, a rima, o ritmo, a imagem e o sistema de cesuras/pausas/silêncios), o poema em prosa exacerba o ritmo e a imagem, pois estes, consoante Octavio Paz (1996), em Signos em rotação, "são inseparáveis. [...] só a imagem poderá dizer-nos como o verso, que é frase rítmica, é também frase que possui sentido" (PAZ, 1996, p. 36). O poema em prosa, enfim, deixando de lado entraves maiores como o verso e a metrificação, relativizando o emprego da rima e da estrofe, valoriza essencialmente o ritmo e a imagem, bases da renovação da poesia da modernidade: esta, ora se preocupa (exteriormente) com a expressão dos ritmos e das imagens da vida e do mundo modernos, cada vez mais complexos, e ora com os ritmos e imagens (interiores) ditados pelo Eu profundo do artista, cada vez mais cônscio do esfacelamento do mundo e de sua fragmentação como 
sujeito para sempre despido de crenças e certezas inabaláveis (a não ser, claro, a crença e a certeza da poesia).

Conforme Massaud Moisés, ritmo deriva do grego rhythmós (movimento regrado e medido, cognato de rheîn, fluir) e "designava primitivamente o fluxo dos rios ou o movimento das vagas oceânicas. Por analogia, passou a ser utilizado em Arte" (MOISÉS, 1995, p. 446). Em decorrência, "pode-se ter como assente que o ritmo se caracteriza pelo tempo, pelo movimento e pela continuidade, que produzem o chamado prazer estético" (1995, p. 447). No que concerne à imagem, Moisés reconhece a instabilidade semântica do vocábulo e propõe a seguinte conceituação, em termos literários:

Teríamos de conceituar a imagem como a pintura por meio de palavras em que estivesse ausente a analogia e a comparação, e, portanto, se ativesse à descrição: o poema nos apresentaria a soma de signos correspondentes à representação, na mente do escritor, dos pormenores sensíveis que compõem os objetos do mundo físico. 0 leitor 'vê' no texto a concretização verbal (imagens visíveis) da representação mental (imagens psicológicas) de um objeto sensível (MOISÉS, 1995, p. 284; grifo do autor).

Creio que a definição do crítico é funcional, mas não compreendo porque dissociar a imagem da metáfora e da comparação: a imagem literária não é apenas descrição, mas também analogia, comparação, justaposição, simultaneísmo na apreensão e representação de objetos, paisagens e pessoas, conforme os simbolistas e os vanguardistas o demonstraram. Por conseguinte, penso que a metáfora é a imagem literária por excelência.

Por seu turno, Octavio Paz assim caracteriza ritmo e metro:

O ritmo se dá espontaneamente em toda forma verbal, mas só no poema se manifesta plenamente. Sem ritmo, não há poema; só com o mesmo, não há prosa.0 ritmo é condição do poema, enquanto é inessencial para a prosa. 
[...] 0 ritmo é inseparável da frase; não é composto só de palavras soltas, nem é só medida ou quantidade silábica, acentos e pausas: é imagem e sentido. Ritmo, imagem e significado se apresentam simultaneamente em uma unidade indivisível e compacta: a frase poética, o verso. 0 metro, ao invés disso, é medida abstrata e independente da imagem. A única exigência do metro é que cada verso tenha as sílabas e os acentos requeridos. [...] Em si mesmo, o metro é medida vazia de sentido. 0 ritmo, pelo contrário, jamais se apresenta sozinho; não é medida, mas conteúdo qualitativo e concreto (PAZ, 1996, p.11-13; grifo nosso).

Evidencia-se, na lição de Paz, a indissociabilidade entre o ritmo do verso e as imagens veiculadas por este, pois é da conjugação desses dois fatores que o poema é capaz de expressar um sentido. A imagem é assim definida pelo poeta-crítico mexicano:

\begin{abstract}
Designamos com a palavra imagem toda forma verbal, frase ou conjunto de frases, que o poeta diz e que unidas compõem um poema. Estas expressões verbais foram classificadas pela retórica e se chamam comparações, símiles, metáforas, jogos de palavras, paronomásias, símbolos, alegorias, mitos, fábulas etc. [...] Cada imagem - ou cada poema composto de imagens - contém muitos significados contrários ou díspares, aos quais abarca ou reconcilia sem suprimi-los (PAZ, 1996, p. 37-38; grifo nosso).
\end{abstract}

As imagens são reais (uma flor vista; o aroma do café sendo coado) ou são frutos da imaginação (uma flor irreal; um sonho). Em ambos os casos, as imagens denotam um valor psicológico. No caso da poesia, a imagem é conotativa - ou uma espécie de desvio, ou ainda uma intencionalidade -, pois, ao reproduzir a pluralidade e a diversidade do mundo real, a imagem outorga-lhe unidade, ou seja, a imagem poética é sempre um discurso sobre o mundo. De acordo com Paz (1996), há diversos níveis de sentido nas imagens utilizadas e veiculadas pela poesia: a) as imagens poéticas são autênticas porque o poeta as viu ou ouviu; elas 
significam sua visão de mundo e sua experiência genuína de percepção da realidade; b) as imagens poéticas reafirmam a intencionalidade do discurso poético, pois "constituem uma realidade objetiva, válida por si mesma: são obras” (PAZ, 1996, p. 45); c) as imagens poéticas validam a poesia como forma superior de conhecimento, pois sempre nos revelam algo sobre nós mesmos ou sobre o mundo, por mais disparatadas que sejam.

Em síntese, aproveitando a lição de Moisés (1995), Bosi (1997) e Paz (1996), é preciso compreender que a imagem plástica é imediata, enquanto a imagem poética é mediata. Quer isto dizer que a imagem na literatura (na poesia, sobretudo) carece do impacto imediato que ela tem na pintura, na fotografia, no cinema ou na escultura (artes visuais, plásticas), pois a imagem literária é construção verbal, mediatizada pela racionalidade do discurso. Tal racionalidade não significa pretensão científica, mas apenas o fato de que uma palavra qualquer - a palavra rosa, a palavra mar, a palavra sol- é constituída, ao mesmo tempo, de som e de sentido: e estes, conjugados no momento da escrita ou da enunciação da palavra rosa, configuram já a imagem de uma rosa. A imagem poética da rosa, portanto, não é a imagem literal (denotativa, em primeiro grau) da rosa na pintura ou na fotografia, mas a imagem em segundo grau (conotativa, polissêmica, sugestiva e intelectualizada) que se depreende, por exemplo, dos seguintes versos de Cruz e Sousa: "Ó Rosa pulcra dos Rosais polares! // Branca, do alvor das âmbulas sagradas" (SOUSA, 1995, p. 69). Sobre isso, leiam-se as palavras cristalinas de Alfredo Bosi (1997), em $O$ ser e o tempo da poesia:

0 tremendo poder de síntese da frase poética envolve a imagem, o conceito e o som [...] Preserva-se, no discurso poético, mais do que em qualquer outro, a intimidade de tais correlações. [...] Subsiste, assim, como processo fundante de toda linguagem poética, a trama de imagem, pensamento e som (BOSI, 1997, p.88, grifos do autor). 
Claro está que a imagem plástica, na pintura, no cinema ou na fotografia, é também fictícia(construída, no sentido da poiesis grega), mas seus elementos constitutivos falam direta e primeiramente aos olhos (aos sentidos), enquanto os elementos constitutivos da imagem poética, decodificados no ato da leitura, falam ao intelecto.

Epifania significa a manifestação do sagrado no mundo. É definida, no Dicionário de teologia bíblica de Johannes Bauer (apud SÁ, 1993), como:

a irrupção de Deus no mundo, que se verifica diante dos olhos dos homens, em formas humanas ou não humanas, com características naturais ou misteriosas que se manifestam repentinamente, e desaparecem rapidamente (BAUER apud SÁ, 1993, p. 168).

A epifania pode dar-se através da teofania (manifestação por meio de sinais), angelofania (aparição de anjos) ou pneumatofania (as línguas de fogo assumidas pelo Espírito Santo, no dia de Pentecostes). Olga de Sá (1993) afirma que a epifania constitui "uma realidade complexa, perceptível aos sentidos, sobretudo aos olhos (visões), ouvidos (vozes) e até ao tato" (SÁ, 1993, p. 168). A partir daqui, a autora estuda os modos personalíssimos como James Joyce e Clarice Lispector, extrapolando a origem bíblica do evento, utilizam a epifania em suas obras: esta

[...] será transformada, por Joyce, em técnica literária, contribuindo, desta forma, para matizar os acontecimentos cotidianos e transfigurá-los em efetiva descoberta do real. A 'escritura epifânica' de Clarice Lispector, nos seus melhores momentos, é procedimento do seu romance metafísico (SÁ, 1993, p. 166; grifo da autora).

Em relação à escritora brasileira, a pesquisadora afirma que, além da gama variada de "epifanias da beleza e visão, existe também outra, 
de epifanias críticas e corrosivas, epifanias do mole e das percepções decepcionantes, seguidas de náusea ou tédio" (SÁ, 1993, p. 200). 0 duplo aspecto assumido pela epifania clariceana talvez encontre sua origem (e isto é apenas uma intuição, uma hipótese de trabalho)na poesia em prosa de Cruz e Sousa (principalmente Evocações [1898]), na qual o autor também explora as imagens visuais da epifania sagrada e da epifania diabólica. 0 contato entre ambos dar-se-ia, a meu ver, porque a revelação epifânica liga-se em profundidade a uma visão analógica de mundo e está ancorada, estruturalmente, na imagem e na percepção sinestésica das realidades empíricas e das realidades do Eu profundo.

\section{A poesia em prosa de Cruz e Sousa}

Missal, o primeiro livro de Cruz e Sousa, escrito sob o impacto simbolista, foi publicado em fevereiro de 1893 e constitui-se de 45 poemas em prosa, em sua maioria bastante curtos. 0 título do livro refere-se, como era praxe na estética simbolista, à liturgia católica, ou seja, o livro em que são reunidas as orações da missa. Missal pode significar ainda uma variedade de caracteres tipográficos, mas, no caso de Cruz e Sousa, é "branco Missal da excelsa Religião da Arte"(SOUSA, 1995, p. 459), como o eu-lírico afirma logo no início da coletânea, no poema "Oração ao sol". Este, ao abrir a recolha, compõe, com o 45ํㅜ poema, "Oração ao mar", uma estrutura circular e harmônica, que, de certa forma, é repetida em Evocações(1898). Assim, a ouverture e o grand finale da obra, sinfonicamente, são poemas de índole panteísta e pagã, e ressaltam a acentuada preocupação do poeta com a forma, a beleza e o preciosismo de expressão. Os dois poemas, nesse sentido, fornecem alguns indícios da arte poética de Cruz e Sousa, evocam a mescla de elementos (artificiais e naturais, católicos e pagãos, noturnos e diurnos, subjetivos e objetivos, etc.) que inunda a obra e revelam como nesta prevalece a adesão ímpar ao símbolo, à musicalidade e à exploração sinestésica de sensações. Estes aspectos somados denotam a plena compreensão da teoria das cor- 
respondências baudelairiana, por parte de nosso poeta. Tais questões gerais, aprofundadas no próximo livro, indiciam como a poesia em prosa de Cruz e Sousa completa e complementa sua poesia em versos, pois se configura como objeto privilegiado de reflexão estética e de autoconhecimento psicológico e intuitivo.

Vejamos como os seguintes excertos de "Oração ao sol", enredados numa profusão de imagens metafóricas, esclarecem alguns pontos frisados acima:

Sol, Rei Astral, deus dos sidéreos Azuis, que fazes cantar de luz os prados verdes, cantar as águas! Sol imortal, pagão, que simbolizas a Vida, a Fecundidade! Luminoso sangue original que alimentas o pulmão da Terra, o seio virgem da Natureza! Lá do alto zimbório catedralesco de onde refulges e triunfas, ouve esta Oração que te consagro neste branco Missal da excelsa Religião da Arte, esmaltado no marfim ebúrneo das iluminuras do Pensamento. Permite que um instante repouse na calma das Ideias, concentre cultualmente o Espírito, como no recolhido silêncio de igrejas góticas [...] Ó radiante orientalista do firmamento! Supremo artista grego das formas indeléveis e prefulgentes da Luz! pelo exotismo asiático desses deslumbramentos, pelos majestosos cerimoniais da basílica celeste a que tu presides, que esta Oração vá, suba e penetre os etéreos paços esplendorosos e lá para sempre vibre, se eternize através das forças firmes, num som álacre, de clarim proclamador e guerreiro (SOUSA, 1995, p. 459-460; grifo nosso).

Como apontou Nestor Vítor (1899), todo o Missal seria, além de conjunto de rezas e procedimentos para a perfeita comunhão e elaboração da arte nova, uma espécie de "clarim proclamador e guerreiro" contra os parnasianos, cujas "regras fósseis" (VÍTOR, 1899, p. 459)o poeta recusa. No poema - em que a pletora de exclamações e maiúsculas revela o sentido espiritual e absoluto conferido a certos vocábulos, além do entusiasmo e da disposição guerreira do eu-lírico -, a imagem do sol é ainda metaforizada como "Sultão dos espaços", "Luz eternal"e "Espírito 
da Irradiação", revelando-se como o único elemento natural (e tal solaridade brilhante é sumamente importante neste livro de Cruz e Sousa) a facultar-lhe a "Graça real" (p. 460) de rir, amar e professar o noviciado da arte nova. Esta, como se vê pelos vocábulos grifados, apreende elementos caros à estética decadentista-simbolista, como o suntuarismo, o aristocratismo, o panteísmo, o orientalismo à Baudelaire, a presença de elementos litúrgicos do Catolicismo, a torre de marfim, o idealismo, a espiritualidade, o arranco para o alto, a visão positiva da existência e da arte. Dentre alguns elementos estilísticos, perceptíveis nos fragmentos citados, temos: a enumeração adjetiva; a metaforização; a sutil preferência pelo adjetivo "eternal" - forma menos utilizada -; a construção pleonástica "marfim ebúrneo", que acusa a figura da redundância semântica, como definida por Jean Cohen (1978).

Outrossim, se cabe ao sol fecundar a arte nova do poeta, caberá ao mar (outro elemento natural fundamental na obra, pois completa a solaridade brilhante a que referi acima)recolher e guardar, a sete chaves, "as Ideias que este Missal encerra" (SOUSA, 1995, p. 516). Preciosamente qualificado, o texto "Oração ao mar", por meio da personificação do mar e das imagens metafóricas brilhantes e suntuosas, também demonstra alguns procedimentos estéticos importantes de Cruz e Sousa:

Ó Mar! Estranho Leviatã verde! Formidável pássaro selvagem, que levas nas tuas asas imensas, através do mundo, turbilhões de pérolas e turbilhões de músicas! Órgão maravilhoso de todos os nostalgismos, de todas as plangências e dolências... Mar! Mar azul! Mar de ouro! Mar glacial! Mar das luas trágicas e das luas serenas, meigas, como castas adolescentes! Mar dos sóis purpurais, sangrentos, dos nababescos ocasos rubros! No teu seio virgem, de onde derivam as correntes cristalinas da Originalidade, de onde procedem os rios largos e claros do supremo vigor, eu quero guardar, vivos, palpitantes, estes Pensamentos, como tu guardas os corais e as algas. [...] Rogo-te, ó Mar suntuoso e supremo! para que conserves no íntimo da tu'alma heroica e ateniense toda esta dolorosa Via-Láctea de sensações e ideias, estas emoções e formas 
evangélicas, religiosas, estas rosas exóticas, de aromas tristes, colhidas com enternecido afeto nas infinitas aleias do Ideal, para perfumar e florir, num abril e maio perpétuos, as aras imaculadas da Arte. [...] Pelas tuas alegrias e radiantes garças; pelas alacridades salgadas, picantes, primaveris e elétricas que os matinais esplendores derramam, alastram sobre o teu dorso, em pompas; pelas convulsas e mefistofélicas orquestrações das borrascas; pelo epiléptico chicotear, pelas vergastantes nevroses dos ventos colossais que te revolvem; pelas nostálgicas sinfonias que violinam e choram nas harpas da cordoalha dos Navios, ó Mar! guarda nos recônditos Sacrários d'esmeralda as Ideias que este Missal encerra, dá-o, pelas noites, a ler às meditadoras Estrelas, à emoção dos Angelus espiritualizados e, majestosamente, envolve-o, deixa que Ele repouse, calmo, sereno, por entre as raras púrpuras olímpicas dos teus ocasos... (SOUSA, 1995, p. 515-516; grifo do autor).

Com estas palavras (suspensas pelas reticências), encerra-se Missal. Conjugado a Sol, o Mar aparece como importante imagem simbólica, completando-se então a solaridade brilhante e aquática da obra: ao encerrar esta nos "recônditos Sacrários d'esmeralda" (SOUSA, 1995, p. 516) do mar, é como se o poeta procedesse ao próprio batismo nas águas lustrais e cristalinas para finalmente ascender ao plano solar e espiritual, onde "estes Pensamentos acerbos viverão para sempre, à augusta solenidade dos astros resplandecentes" (SOUSA, 1995, p. 515-516).

Ressaltem-se, nos fragmentos, a presença de neologismos como "violinam" (p. SOUSA, 1995, 516)e "nostalgismos" (SOUSA, 1995, p. 515); o uso de palavras como "dolências" e "plangências", muito valorizadas no geral da obra do poeta; as enumerações adjetivas e substantivas, que provocam a exploração sinestésica e revelam o impressionismo, de forte apelo sugestivo e imagético, que entranha todo o Missal; a qualificação metafórica deste como "Via-Láctea de sensações e ideias [e] rosas exóticas, de aromas tristes, colhidas com enternecido afeto nas infinitas aleias do Ideal" (SOUSA, 1995, p. 516), dão bem uma idéia das enumerações e do caráter espiritual da obra. 
Evocações, pronto desde 1897, só veio a lume em 1898, postumamente, numa edição patrocinada por Saturnino Meireles. Compõe-se de 36 textos: alguns são bastante curtos, caracterizando-se melhor como poemas em prosa; outros, verdadeiros contos simbolistas; outros, ainda, ensaísticos, delineadores da arte poética cruciana, oferecem variadas reflexões sobre a arte e o artista. No geral, como encontramos em Últimos sonetos(1905), há o aproveitamento estético dos problemas humanos e sociais vividos pelo poeta, ora plenamente consciente do trabalho com a linguagem, ora cônscio da transcendência do Eu e da busca de uma forma literária maleável, apta à expressão de seus conturbados conteúdos psíquicos. Portanto, sob o diapasão simbolista-decadentista-expressionista, Evocações (1898) oferece páginas em que a escavação dos meandros inconscientes e do universo onírico se dá por meio da deformação expressiva, da análise psicológica e da consciência da Dor metafísica.

Evocações - simbolista já pelo título sugestivo grafado no plural, na generalidade da titulação - "atribui a cada um dos textos a atmosfera de mistério", conforme observa Luiz Silva (1999, p. 77) em seu trabalho Um desafio submerso: Evocações, de Cruz e Sousa, e seus aspectos de construção poética, dissertação de Mestrado defendida na UNICAMP, em 1999. O plural do título geral induz ainda, segundo o autor (SILVA, 1999, p.77), "a que se tome a obra por um conjunto de procedimentos ritualísticos para despertar instâncias passadas ou desconhecidas". Neste sentido, dois paradigmas claramente se impõem: a memória e a transcendência, sendo que "à imaginação caberá o papel de costurar o discurso nas duas direções, já que a obra não se sedimenta sobre a linguagem referencial” (SILVA, 1999, p.77; grifo nosso). Evocar, frisa Luiz Silva, "aponta para o conteúdo místico da linguagem, seu poder encantatório, [...] na evocação souseana com a palavra chega-se aos estratos profundos da dimensão humana" (SILVA, 1999, p. 160). Detendo-se no significado de evocar(chamar, fazer aparecer, trazer à lembrança) e invocar(chamar, pedir proteção ou auxílio, suplicar, recorrer), Silva estabelece a seguinte distinção: 
As evocações, no sentido da obra, poderiam ser tidas como textos resultantes de um empenho, de um propósito de fazer aparecer algo, o que implica, portanto, em afrontar o ocultamento, o não-dito, o interdito. Por outro lado, as evocações podem estar sinalizando, também, para uma forma de escrita, que tem como função básica estimular sensorialmente e revelar as camadas obscuras da subjetividade. (SILVA, 1999, p. 77).

Luiz Silva, na conclusão de seu trabalho, toca em outras questões pertinentes, como o processo de recepção da obra, sua marginalidade estética e social, sua ligação com a tradição Poe-Baudelaire e a maneira como esta responde, estética e existencialmente, ao momento sociocultural do poeta, marcado pelo positivismo cientificista. Por conseguinte, Silva ressalta que Evocações confronta "o cânone literário e social, em nome da liberdade artística e subjetiva", sendo "a resposta da periferia que se tornou centro"; a "linguagem desafiadora" do livro instaura o novo "de forma desconcertante, exigindo do leitor a disposição para a aventura por caminhos desconhecidos" (SILVA, 1999, p. 186-187). Embora muito mais esteticista que Evocações, penso que a Missal também se aplicam as várias considerações de Luiz Silva, uma vez que as duas obras, lidas em conjunto (segundo empreendo na tese de doutoramento, inclusive classificando os textos de cada uma em grupos temáticos e formais afins), muito esclarecem sobre os aspectos éticos e estéticos da obra de Cruz e Sousa. Afirmo isto porque Missal e Evocações exacerbam os vários níveis de transgressão e ruptura efetivados pelo poeta - conquanto, pelo preciosismo, sejam tidas pela crítica tradicional como inferiores à obra em versos do artista (mais um preconceito, frise-se, porque ambas - repita-se - complementam, esclarecem e justificam, estética e eticamente, numa espécie de diálogo intratextual, a produção em versos do Dante Negro).

Evocações, conforme já aventado, também apresenta certa estrutura circular e harmônica. 0 livro abre-se com "Iniciado", verdadeiro programa simbolista cruciano que, além da consciência da Dor metafísica, que 
tanto marca a poesia de Cruz e Sousa, questiona, também, a condição do Artista, tido como um ser eleito e iniciado. No texto encontra-se um fragmento que poderia ser tomado como epitáfio do poeta: "A Arte dominou-te, venceu-te e tu por ela deixaste tudo" (SOUSA, 1995, p. 520). Ainda em "Iniciado", justifica-se a busca da torre de marfim como um meio de evasão e reclusão necessárias: longe da turba burguesa, materialista e positivista, o poeta pode dedicar-se a seu trabalho supremo:

Para resistir aos perturbadores ululos do mundo fecha-te à chave astral com a alma, essa esfera celeste, dentro das muralhas de ouro do Castelo do Sonho, lá muito em cima, lá muito em cima, lá no alto da torre azul mais alta dentre as altas torres coroadas d'estrelas. (SILVA, 1999, p. 523).

Em "Emparedado", poema que fecha Evocações e completa o círculo de subjetividade e de reflexões sobre o poeta, a arte, o Eu e o mundo, dirse-ia que o eu-lírico, ouvindo a "voz ignota" (SILVA, 1999, p. 672) que lhe fala, é compelido a aceitar a torre de marfim de sua própria condição de filho "de Cam, réprobo, anatemizado!” (p.672). A qualificação da "voz ignota" dá bem a medida do clima que perpassa todo o livro: a voz "parece vir do fundo da Imaginação ou do fundo mucilaginoso do Mar ou dos mistérios da Noite - talvez acordes da grande Lira noturna do Inferno e das harpas remotas de velhos céus esquecidos" (p.672). Essa torre de marfim, em contraposição à imagem de "Iniciado", não é de ouro ou de gemas preciosas - mas de pedra; negras pedras -, e aprisionam o poeta dentro do próprio sonho, como que solidificando a metáfora que ele usa para qualificar sua condição social:

Falas em Abstrações, em Formas, em Espiritualidades, em Requintes, em Sonhos! Como se tu fosses das raças de ouro e da aurora, se viesses dos arianos, depurado por todas as civilizações [...] Artista! pode lá isso ser se tu vens d'África, tórrida e bárbara, devorada insaciavelmente pelo deserto [...] A África laocoôntica, alma de trevas e de chamas [...] Artista? Loucura! Loucura! Pode lá isso ser se tu vens dessa longínqua região 
desolada, [...] dessa África dos Suplícios, sobre cuja cabeça nirvanizada pelo desprezo do mundo Deus arrojou toda a peste letal e tenebrosa das maldições eternas! A África virgem, inviolada no Sentimento, avalanche humana amassada com argilas funestas e secretas para fundir a Epopeia suprema da Dor do Futuro, para fecundar talvez os grandes tercetos tremendos de algum novo e majestoso Dante Negro! [...] Não! Não! Não! Não transporás os pórticos milenários da vasta edificação do Mundo [...] para a direita [...] [a] parede horrendamente incomensurável de Egoísmos e Preconceitos! [...] para a esquerda, outra parede, de Ciências e Críticas [...] para a frente, ainda nova parede, feita de Despeitos e Impotências [...] para trás, ah! ainda, uma derradeira parede, fechando tudo, fechando tudo - horrível - parede de Imbecilidade e Ignorância [...] E, mais pedras, mais pedras se sobreporão às pedras já acumuladas, mais pedras, mais pedras... Pedras destas odiosas, caricatas e fatigantes Civilizações e Sociedades... Mais pedras, mais pedras! E as estranhas paredes hão de subir, - longas, negras, terríficas! Hão de subir, subir, subir mudas, silenciosas, até às Estrelas, deixando-te para sempre perdidamente alucinado e emparedado dentro do teu Sonho... (SILVA, 1999, p. 672-673).

Estas são as palavras finais de Evocações - também suspensas por reticências, mas quão distantes estamos do aparato brilhante do Sol e do Mar, que fecundava (o primeiro) e guardava (o segundo) o Missal do poeta! No entanto, ele continua fiel aos preceitos de sua arte, pois, mesmo emparedado vivo, responde orgulhosamente com o que tem de mais precioso: sua poesia; seu trabalho com a palavra; a disposição e a possibilidade de, por meio de novas formas poéticas, escavar os mistérios do Eu e do Outro, da Vida e do Mundo, das Estrelas e da Noite. Evidencia-se, aqui, como o poeta atualiza o tópico decadentista-simbolista do poeta maldito, ligando-o à sua própria condição desgraçada, de pária social.

Em suma, à profissão de fé formalista, impressionista e superficialmente decorativa de Missal, as Evocações respondem com uma maleabilidade ainda maior na configuração dos textos, com um acentuado expressionismo, com a adesão plena ao Simbolismo e com uma utilização sui generis, personalíssima, do aparato negativo da estética decadentis- 
ta. 0 poeta continua preocupado com a invenção poética, mas a esta é acrescentado um recurso que estava praticamente ausente de Missal: a repetição (de palavras, expressões, frases poéticas, temas, motivos e imagens noturnas, conforme evidenciam já os fragmentos citados), com a qual o eu-lírico pretende conferir evidente ritmo novo à expressão, mas também enfatizar suas evocações profundas, provocar a atenção do leitor para algo importante e/ou fundamental, denunciar uma situação, um estado de alma, etc. Assim, estruturalmente, a repetição torna-se um dos elementos-chave de Evocações, que nos reserva ainda algumas outras surpresas. Dentre estas, a constatação de que o livro se cristaliza sob o império da Noite(a Noite real e a Noite da alma, como metáfora dos meandros inconscientes e profundos do poeta). Portanto, a solaridade brilhante de Missal, calcada no esteticismo, é substituída em Evocações pela noturnidade metafísica, mais reveladora do íntimo do artista e de sua condição de poeta duplamente maldito. Tal caminho é percorrido também na poesia em versos de Cruz e Sousa, de Broquéis (1893) a Faróis (1900) e Últimos sonetos (1905). 0 que persiste, de Missal a Evocações, é a ânsia do poeta em criar um mundo paralelo, artificial e requintado, só possível pela poesia. Para isso, utiliza-se de uma linguagem hermética, sugestiva e musical, onde as imagens (respectivamente, diurnas e noturnas; solares e infernais; reais e oníricas) surpreendem pela raridade. Assim, conclui-se que a melopéia (o apreço pela musicalidade) e a fanopeia (o modo de apreensão e configuração das imagens, no discurso poético) não são apenas recursos de ornamentação, mas elementos estruturais importantíssimos na construção da poesia simbolista de Cruz e Sousa. E é da junção inextrincável destas (imagens e musicalidade) que se nos revela o pensamento ético-estético (a logopeia, vale dizer) profundo de Cruz e Sousa, que viveu na pele e na alma as contradições da sociedade brasileira do final do século XIX, dramatizando-as em prosa e em verso. 
PIRES, A. D. Imagem e epifania nos poemas em prosa de Cruz e Sousa

\section{O lírio e a lesma}

Percorrendo Missal e Evocações em busca de um possível símbolochave abraçado por Cruz e Sousa, constata-se que este se constrói a partir da tensão permanente de duas imagens simbólicas caras ao poeta: o lírio e a lesma. Tal imagem antitética é irredutível a uma síntese apaziguadora e, para sempre, presentifica e exacerba o significativo contraste que permeia a vida e a obra do poeta, em todos os seus níveis: éticos e estéticos, positivos e negativos, claros e escuros, solares e noturnos, pessoais e sociais, naturais e artificiais, etc.

Em primeiro lugar, a imagem do lírio aparece disseminada nos dois livros do autor, geralmente como metáfora e/ou símbolo de pureza, espiritualidade ou beleza, e pode estar ligada à figura feminina ("teu corpo de garça, lirial e formoso" - p. 505); à divindade("cismadoras Imagens liriais dos hagiológios" - p. 492); a aspectos da natureza ("À luz lirial da lua" - p. 498-499); à figura do artista("Lírio estético" - p. 622). Cruz e Sousa, em sua ânsia por neologismos, conquanto utilize bastante o substantivo lírio, também o toma como adjetivo ("um tecido d'estrelas, liriais e siderais" - p. 481), verbo ("a lua liriava" - p. 654) ou advérbio ("lirialmente alvo" - p. 512). Veja-se como o poeta, de forma metalinguística, define lírio: "um lírio branco, - florescência simbólica das castidades místicas, forma cândida e aromal de volúpias sagradas e noviças..." (p. 637). Este sentido espiritual, brilhante, suntuoso, sinestésico e epifânico é que sempre se liga a lírio e seus derivados.

O substantivo lesma, por outro lado, aparece como imagem apenas em Evocações, e isso se explica pelo clima noturno e soturno do livro, revelador, em larga medida, do caos e do magma negro do inconsciente do eu-lírico. Assim, lesma- e seus derivados - é sempre utilizado em sentido negativo, de sujidade, de repugnância e de escuridão, em contraste evidente com o símbolo lírio. Veja-se como o poeta, em "Asco e dor", explora a negatividade semântica do vocábulo em imagem que revela sua repugnância e sua dor ao constatar a inconsciência e a miséria dos negros seus iguais, ora mascarados para uma festa de Carnaval: 
Asco que era para mim como se eu me sentisse coberto de lesmas, lesmas fazendo pasto no meu corpo, lesmas entrandome pelos ouvidos, lesmas entrando-me pelos olhos, lesmas entrando-me pelas narinas, pela boca asquerosamente entrando-me lesmas. Um asco feito de sangue, lama e lágrimas. (SOUSA, 1898, p. 574; grifo nosso).

Vejam-se outros exemplos, em que a palavra lesma pode aparecer como substantivo comum, como metáfora ou, de forma derivada, como adjetivo e verbo: "langue lesma negra" (p. 614); "ele, miseranda lesma” (p. 636); "peçonha lesmenta, larvosa, da Morte" (p. 597); "O corpo hirto, [...] tressua um frio horrível, lesmento" (p. 594); “te arrastas, lesmado e vil" (p. 617); "a invasão sinistra dos reptis verdes da inveja lesmando tudo" (p. 640).

Creio ser evidente, pelos fragmentos citados, que os significados mais comuns, suscitados pelos vocábulos grifados, referem-se a aspectos escuros, sombrios ou repugnantes como asco, frio, morte, decomposição, profanação, viscosidade, sujeira. Ou seja, lesma, enquanto imagem metafórica e/ou simbólica de uso restrito a Evocações, revela o império da Noite (natural e pessoal; simbólica e metafísica; sonhadora e psíquica) em que o livro é fundado. É da Noite (da morte, do escuro, do medo, da inconsciência, do sonho e, inclusive, da marginalidade social), que podem surgir essas estranhas e asquerosas larvas, pegajosas e peçonhentas, a roer fundo, a sangrar, a esquadrinhar os recessos profundos e caóticos do eu-lírico. É também da Noite (do sonho, do inconsciente, da prisão de negras pedras), por outro lado, que brotam as estranhas e puras flores astrais, liriais, das estrelas e da Poesia.

Em abono do afirmado acima é mister assinalar, de Últimos sonetos(1905), o antepenúltimo verso do poema "O grande momento", que aponta na mesma direção da leitura aqui proposta: "Borboleta de sol, surge da lesma..." (p. 184).

Com isso, penso ter evidenciado como o simbólico embate claro e escuro, diurno e noturno, vida e morte, consciência e inconsciência, etc., 
tensionado em lírio e lesma, está presente de forma bastante entranhada na poesia em prosa de Cruz e Sousa, enfatizando sua cosmovisão profunda e original, seja em termos de consciência estética, seja em termos de resposta pessoal ao tópico decadentista-simbolista do poeta maldito, seja por sua consciência das relações analógicas entre macrocosmo e microcosmo. Em complemento, a visão epifânica configurada nos poemas em prosa remete à conclusão de que estes, mesmo apresentando certo formalismo e evidente iluminação - para usarmos os termos de Suzanne Bernard (1959)-, enquadram-se melhor como poemas-epifania (epifanias que, como vimos, incluem o divino sublime e o demoníaco grotesco), numa demonstração de como nosso poeta soube, também neste particular, dar voz personalíssima à matriz e à tradição francesas do poema em prosa.

Enfim, a poesia de Cruz e Sousa (em prosa e em versos) ajuda a configurar a nascente modernidade literária brasileira, quer pela temática e pela valorização da liberdade artística, dissolvendo os gêneros literários e os conceitos tradicionais de prosa e poesia, quer pela busca místico-analógica da pureza metafísico-espiritual e pela escavação dos conteúdos profundos do Eu, aspectos que conferem plena universalidade a nosso simbolista maior. Por tudo isso, o poeta do Desterro tem assegurado por méritos próprios, evidentemente - seu espaço peculiar nos quadros da literatura brasileira.

\section{REFERÊNCIAS}

BERNARD, S. Le poème en prose de Baudelaire jusqu'à nos jours. Paris: Nizet, 1959.

BOSI, A. 0 ser e o tempo da poesia. São Paulo: Cultrix, 1997. COHEN, J. Estrutura da linguagem poética. 2. ed. São Paulo: Cultrix, 1978. 
LEFEBVE, M.-J. Estrutura do discurso da poesia e da narrativa. Coimbra: Almedina, 1980.

MOISÉS, M. Dicionário de termos literários. 7. ed. São Paulo: Cultrix, 1995.

PAZ, O. Signos em rotação. 3. ed. São Paulo: Perspectiva, 1996 (Debates, 48).

PIRES, A. D. Pela volúpia do Vago: o Simbolismo. 0 poema em prosa nas literaturas portuguesa e brasileira. 2002. $457 \mathrm{f}$. Tese (Doutorado) - Faculdade de Ciências e Letras, UNESP, Araraquara, SP, 2002 (2 volumes).

SÁ, O. de. O conceito e o procedimento da epifania. In: A escritura de Clarice Lispector. 2. ed. Petrópolis: Vozes, 1993. p. $163-211$.

SILVA, L. Um desafio submerso: Evocações, de Cruz e Sousa, e seus aspectos de construção poética.200 f. Dissertação (Mestrado) - Instituto de Estudos da Linguagem, UNICAMP, Campinas, SP, 1999.

SOUSA, J. da C. e. Obra completa. Organização de Andrade Muricy. Atualização e notas de Alexei Bueno. Reimpressão atualizada da 1. ed. Rio de Janeiro: Nova Aguilar, 1995.

VITOR, N. Cruz e Sousa. In: COUTINHO, A. (Org.) Cruz e Sousa. Rio de Janeiro: Civilização Brasileira: Brasília INL/MEC, 1979, p. 104-145. 